
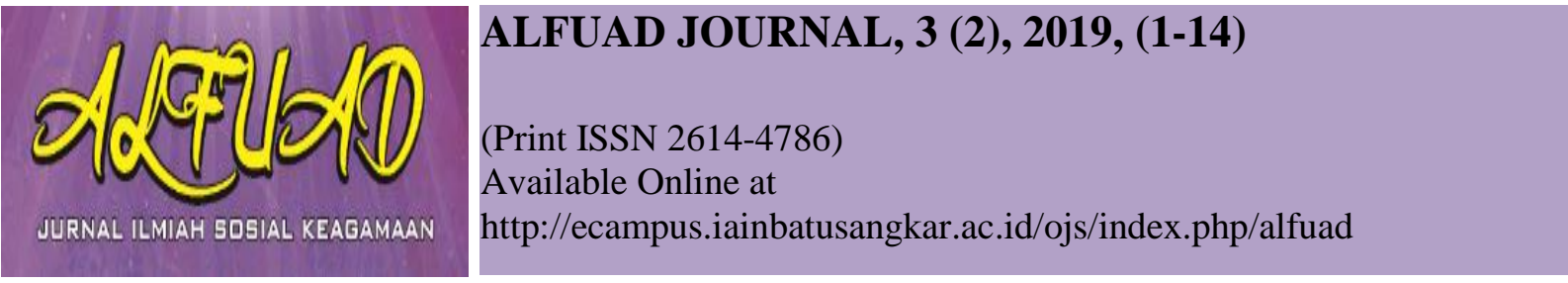

\title{
KONSEP PENDIDIKAN KARAKTER DALAM PENGEMBANGAN MASYARAKAT ISLAM (STUDI PEMIKIRAN BURHANUDDIN AL-ZARNUJI)
}

\author{
Rahmat hidayat \\ Institut Agama Islam (IAI) An Nur \\ Lampung \\ E-mail: hidayatrahmat677@gmail.com
}

\begin{abstract}
A basic implementation of value in education is character. Growing the style and distinctive characteristic is not a job in reversing the palm. However, various processes and stages are done as an effort to achieve this. Burhanuddin Al Zarnuji is a reformer philosopher and provides a theoretical contribution in the world of Muslim renewal and Western. His opinion was expressed as a form of servitude to God for all the opportunities given to humans during his lifetime. Character education is a very much needed concept in today's world. Deterioration and slump morality in the joints of life has resulted in social phenomenology being a special concern from various groups of ordinary people to the elite. Deterioration of character caused by the nature of jumawa over scientific knowledge without propped up there is still the sky above the sky resulting in awareness of living together being blurred. Then the concept of building character is an awareness of how character is an interpretation of ahlakulkarimah in every human life. Society, practitioners and governments are a very similar pattern as an effort to run a concept of character education integration in a theoretical level. It is conceptualized in Zarnuji with several discussions; a). Understanding the science of Fiqh and its importance, b). Intention when studying, c). Choose a science, teacher, friend, and about fortitude, $d$ ). Respect for science and scholars, e). Diligent, continuity, and interest, f). Beginning, size and discipline of learning, $g$ ). tawakal, $h$ ). Fruit revenue from science, i). Compassion and advice, j). Benefit, $k$ ). When learning, l). Causes to memorize and forget, $m$ ). A good fortune and a fortune barrier, and lengthening and deduction of knowledge. The simplified into three concepts namely; 1). The division on knowledge, 2). The purpose of learning, and 3). Method of study.
\end{abstract}

Keywords: Education, Character, Development, Islamic Society

\section{PENDAHULUAN}

Keyakinan dengan garis besar akan kemaslahatan yang dibangun seiring dari cita-cita bangsa Indonesia ialah menjadi bangsa yang bermartabat dan memiliki andil di dalam kesertaan aksi dunia internasional (actiont in the word of hummanity). Keyakinan besar tersebut dapat dijunjung dengan salah satu konteks berkesinambungan wawasan keilmuan 
yang tinggi dengan yang namanya nilai dasar alamiah manusia atau ahlak.

Pada bagian dan unsur kehidupan manusai merupakan sebuah nilai yang segmentasinya menjadi arus di dalam penjabaran ahlak. Kehidupan sosial, budaya dan hubungan menjadi corak yang dianggap dapat menjelaskan survivel nya sebuah nilai yang sangat fundamental dan mengkristal dari masing-masing hati manusia yaitu qolbu (hati). Segmen dalam kehidupan masyarakat dianggap dapat menjelaskan secara rigit akan kesertaan berbagai pihak dalam mengakses tinjauan ilmu pengetahuan sehingga berbeda tingkatan dan perspektif dalam menyikapi konteks hidup.

Dalam konteks Islam kita mengenal sebuah kajain akan yang namanya ghozul fikr dan konteks ini akan memberikan efek samping yang berbeda dalam kajian ilmiahnya. Pertama, sebagai tempaan keimanan seorang hamba akan sikap kewaspadaan dalam mempersiapkan persaingan moral dan nilai. Kedua, memberikan keleluasaan untuk moral dan nilai dapat berjaya dengan menjadikan titik dasar setiap pondasi manusai untuk mengerti dan menyadari hakikat karakter, baik karakter individual dan terlebih bangsa serta agama.

Ahir-ahir ini jika kita menganalisa terkait dengan kaian moralitas, miris rasanya jikalau kita mengatakan konteks moralitas disekeliling kita banyak mengalami degradasi moral/ nilai. Lapisan masyarakat dituntut untuk mampu mencerna kontekstualisasi degradasi moralitas yang sedang terjadi. Karena hal ini sudah bukan menjadi sebuah rahasia umum terkait dengan pembahasan moral yang sudah ada di dalam setiap sendi kehidupan masyarakat. Dimulai dari sebuah pembahasan yang membicarakan konteks bernegara, pendapat kalangan bawah hingga dengan sampai pada elit yang memperhatikan bahwasanya Indonesia adalah negara besar yang bermartabat dengan karakteristiknya haruslah jangan mengalami yang namanya krisis moral. Dan klimaks yang sangat diperhatikan dengan khusus ialah terkait dengan sebuah segmen kehidupan masyarakat luas akan pendidikan karatker/ moral. Banyak kalangan masyarakat, konsep pendidikan terkait nilai moralitas yang satu ini telah mengalami diskursus nnilai, sehingga kalimat krisis moral sering terlontar dengan kesadaran dan keprihatinan.

Dikatakan dalam sebuah buku Best Practice Character Building karangan Erie Sudewo penukilan Anas Shalahuddin dan Irwanto Alkrienciehie bahwa kemelut Indonesia yang semakin carut marut ini iyakini karena ketiadaan karakter (Salahudin, 2013: 31). Karena dalam konsepnya, sebuah negara akan diibaratkan 
tidak memiliki sebuah jiwa dan terlihat rapuh dari luar dikala tidak memiliki sebuah nilai dasar yaitu moral bangsa. Terombang-ambing dalam kekalutan dan ketidak pastian dalam menentukan arah sebuah perjalanan bangsa. Terlebih jikalau kita melihat sejarah,bangsa Indonesia dibangun atas dasar sifat moral/ nilai yang luhur dan inilah yang mencirikan sebuah kekokohan moral bangsa yang besar.

Realitas yang ada, rendahnya nilai karakter bangsa ini semakin membuat dekadensi moral yang tidak hanya dibuat oleh rakyat tapi juga merambah kepada para penguasa pemerintahan, hal ini terbukti dengan semakin banyaknya para penguasa yang ditangkap KPK (Komisi Pemberantasan Korupsi) karena kasus korupsi dan penyelewengan wewenan (Syarbini, 2014: 1). Ditambah dengan permasalahan-permasalahan yang ada pada generasi penerus bangsa remaja, kasus remaja yang notabenenya adalah sebagai status pelajar juga semakin memprihatinkan dengan banyaknya penyimpangan akhlak seperti masalah narkoba (Salahudin, 2013: 32), hubungan seksual pranikah, aborsi, perkelahian, tawuran dan kekerasan. Bahkan tak urung semakin merebaknya kasus dan masalah tersebut banyak menuai kerugian besar bagi kita, banyak pula jiwa yang melayang siasia hanya dengan semakin kritisnya moralitas.
Fenomena inilah yang membuat betapa dunia pendidikan di Indonesia tidak dapat menahan kemerosoton karakter yang terjadi. Ini merupakan akibat dari titik berat pendidikan yang masih lebih banyak pada masalah kognitif (Zainuddin, 2009: 263-264). Penentu kelulusanpun masih lebih banyak pada prestasi akademik dan kurang memperhitungkan akhlak dan budi pekerti siswa. Bahkan jika dilihat dari sudut global, munculnya banyak masalah yang mendera bangsa Indonesia adalah akibat rendahnya moral dan karakter para pelaku kebijakan yang juga diikuti oleh rendahnya etos kerja masyarakat. Sederhananya solusi yang tepat adalah menerapkan pendidikan yang berlandaskan karakter.

Pada prinsipnya secara umum pendidikan karakter tidak dapat tercipta dengan cara instan atau cepat, namun harus melewati suatu proses yang panjang, cermat dan sistematis. Oleh karena itulah Character Education Quality Standards yang dikutip oleh Hamdani Hamid \& Beni Ahmad, bahwa ada 11 prinsip untuk mewujudkan pendidikan karakter yang efektif, yaitu: Mempromosikan nilai-nilai dasar etika sebagai basis karakter.

Mengidentifikasikan karakter secara komprehensif agar mencakup pemikiran, perasaan, dan perilaku. (3) Menggunakan 
pendekatan yang tajam, proaktif dan efektif untuk membangun karakter. (4) Menciptakan komunitas sekolah yang memiliki kepedulian. (5) Memberi kesempatan kepada siswa untuk menunjukkan perilaku yang baik. (6) Memiliki cakupan terhadap kurikulum yang bermakna dan menantang yang menghargai semua siswa, membangun karakter dan membantu mereka untuk meraih kesuksesan. (7) Mengusahakan tumbuhnya motivasi diri para siswa. (8) Memfungsikan seluruh staf sekolah sebagai komunitas moral yang berbagi tanggung jawab, untuk pendidikan karakter yang setia pada nilai dasar yang sama. (9) Adanya pembagian kepemimpinan moral dan dukungan luas dalam membangun inisiatif pendidikan karakter. (10) Memfungsikan keluarga dan anggota masyarakat sebagai mitra dalam usaha membangun karakter.

Mengevaluasi karakter sekolah, fungsi staf sekolah sebagai guru-guru karakter dan manifestasi karakter positif dalam kehidupan siswa.

Selanjutnya berdasarkan betapa pentingnya akhlak atau karakter dalam pendidikan sehingga Allah mengabadikannya dalam QS. Al-Qalam:4

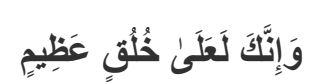

Dan Sesungguhnya kamu benarbenar berbudi pekerti yang agung.

Ayat di atas menjadi kunci betapa Allah sangat menekankan kepada HambaNya ummat manusia untuk mengedepankan dan memiliki akhlaq yang mulia karena ini sebagai ciri atau corak bahwasanya sebuah bangsa atau negara dan individu dengan karakter yang unggul dan kompeten. Hal tersebut terbukti dengan Allah mengutus seorang hamba yang sangat mulia dengan perangai akhlaknya, menjadi pujian dari berbagai kalangan karena sebuah sifat yang sangat mengkristal dengan kepiyauan serta kecakapan di dalam pergaulan. Kemudian Sukro Muhab yang dikutip oleh Anas Salahudin dalam bukunya Pendidikan Karakter, Oleh karena keteladanan dan akhlak Nabi Muhammad inilah yang sehingga menggugah seorang Mahatma Gandi dengan menyatakan: "Saya lebih dari yakin bukanlah pedang yang memberikan kesadaran pada Islam pada masanya, Tapi, ia datang dari kesederhanaan, kebersahajaan, kehati-hatian Muhammad serta pengabdian luar biasa kepada teman dan pengikutnya, tekadnya, keberaniannya serta keyakinannya pada Tuhan dan tugasnya" (Salahudin, A., 2013: 34) 
Dari fenomena pendidikan akhlak atau karakter tersebut, sehingga banyak dari para ahli yang membahas tentang pendidikan akhlak atau dikenal sekarang dengan istilah pendidikan karakter. Diantaranya Burhanuddin al-Zarnuji. Dengan berbagai kitab yang dikarang oleh para ahli tersebut sehingga menunjukkan akan pentingnya pendidikan karakter yang merupakan tujuan puncak dari pendidikan dengan membentuk karakter positif dalam perilaku anak didik. Dan karakter positif itu sendiri tiada lain adalah penjelmaan sifat-sifat mulia Tuhan dalam kehidupan manusia.

\section{PEMBAHASAN}

\section{Konsep Dasar Pendidikan Karakter}

Dalam kurun waktu kurang lebih sebelm tahun 2003 pemerintah telah merancang sebuah undang-undang yang diharapkan akan mengakomodir berbagai permasalahan yang berkaitan dengan dunia pendidikan. Diantaranya ialah penjabaran dan pembahasan akan peraturan perundang-undangan yang membahas tentang pendidikan karakter. Dikarenakan pendidikan karakter sejatinya telah lama menjadi pembicaraan dan perhatian dari pemerintah. Maka pada tahun 2003 di dalam sebuah Undang-Undang Nomor 20 tahun 2003 tentang Sistem Pendidikan Nasional pada pasal 1 (satu) antara lain disebutkan bahwa pendidikan adalah sebuah usaha sadar dan terencana untuk mewujudkan suasana belajar dan proses pembelajaran agar peserta didik secara efektif dan aktif mampu mengembangkan potensi dirinya untuk dituntut memiliki kekuatan spiritual keagamaan, pengendalian diri, kepribadian, kecerdasan, ahlak mulia dan life skill.

Pendidikan karakter menjadi tanggujawab bersama bagi semua pihak, tidak terlebih guru atau dunia pendidikan dan akan tetapi dalam kehidupan masyarakat atau keluarga dinilai menjadi titik tekan yang sanngat efektif dan evisien. Kemudian di dalam menciptakan sebuah pendidikan karakter, kesemuanya itu haruslah dimulai dari pendidik itu sendiri. Akan tetapi kadang kala kita menjadi bumerang, masih banyak pada saat ini banyak kita temukan karakter negatif yang justru berawal dari seorang pendidik itu sendiri.

Maka pada dasarnya corak pendidikan haruslah mencerminkan keselarasan antara nilai-nilai luhur pengetahuan dan ruhaniah. Corak atau ciri merupakan sebuah nilai yang termanifestasikan atas dasar melakukan sebuah pekerjaan untuk merubah, dari sebuah nilai yang bersifat kecil pada besar dan sebuah upaya dari yang buruk pada kebaikan. Karena dalam bahasa 
Yunani, corak ialah mengukir. Dalam memberikan dan melahirkan sebuah konten yang dinamis sebagai upaya menentukan tatanan yang sesuai dengan karakteristik obyek yang melakukan perubahan atau menunjukan jati dirinya. Mengaplikasikan nilai kebaikan dalam bentuk tindakan atau tingkah laku, sehingga orang yang tidak jujur, kejam, rakus dan perilaku jelek lainnya dikatakan orang berkarakter jelek. Sebaliknya, orang yang berprilaku sesuai dengan kaidah moral disebut dengan berkarakter mulia (Daryanto, 2013: 9). Sedangkan dari segi terminologi, karakter sering dipandang sebagai cara berfikir dan berperilaku yang menjadi ciri khas tiap individu untuk hidup dan bekerjasama, baik dalam lingkungan keluarga, masyarakat, bangsa dan negara. Individu yang berkarakter baik adalah individu yang bisa membuat keputusan dan siap mempertanggungjawabkan setiap akibat dari keputusan yang ia buat (Hamid, H., 2013: 7).

Secara teoritik apabila kita memandang dalam konteks linguistik seperti yang dikemukakan oleh Anas Shalahuddin dan Irwanto Alkrienchiehie yang dengan gamblang menjelaskan akan beberapa pengertian yang membahas masalah tersebut, diantaranya; (1) Karakter adalah bawaan, hati, jiwa, kepribadian, budi pekerti, perilaku, personalitas, sifat, tabiat, temperamen, atau watak yang secara hakikat memang sudah melekat pada diri seseorang sejak dimulainya kehidupan. (2) Karakter mengacu pada serangkaian sikap (attitudes), perilaku (behaviors), motivasi (motivations), dan keterampilan (life skill). (3) Karakter adalah watak, tabiat, akhlak, atau kepribadian seseorang yang terbentuk dari hasil internalisasi berbagai kebajikan yang diyakini dan digunakan sebagai landasan cara pandang, berpikir, bersikap dan bertindak. (4) Karakter adalah cara berpikir dan berperilaku yang menjadi ciri khas atau corak sifat setiap individu untuk hidup dan bekerja sama baik keluarga, masyarakat atau bangsa (Salahudin, 2013: 44).

Kemudian disisi lain sebagai pembahasan sebagian tentang karakter, terdapat sebuah pembahasan yang menyatakan dengan sebuah pengistilahan dengan karakter secara konsepnya sering dijelaskan dengan apa yang sering kita sebut dengan sebuah tempramen. Sehingga terdapat sebuah pembahasan di dalam jabaran Doni Koesmono yang dikutip Jamal Ma'ruf Asmani menyatakan defenisi tersebut menekankan konteksnya dalam pisikososial yang dikaitkan dengan unsurunsur pendidikan dan lingkungan (Asmani, 2012: 28-29).

Dalam pembahsan lain Muchlas Samani menjalaskan bahwa yang namanya 
karakter tersebut dimaknai sebagai sebuah cara fikir dan perilaku yang memiliki sifat dan corak yang berbeda antara manusia untuk dapat bekerja sama dan hidup dalam lingkungan kecil dan luas atau untuk bermasyarakat, berbangsa dan bernegara (Samani, 2011: 41). Sedangkan berbeda dengan Haedar Nashir yang menjelaskan bahwa karakter sering pula dikaitkan dengan nilai kepribadian, sehingga pembentukan sebuah karakter juga dihubungkan dengan pembentukan sebuah kepribadian (Natsir, 2013: 11).

Upaya menjabarkan berbagai pengertian dan ungkapan penjelasan di atas maka kita dapat tarik sebuah benanglurus bahwasanya karakter menjadi sebuah lokomotif dalam manusia atau individu untuk menentukan sebuah jalan kedepan dalam sebuah kehidupan. Dengan kata lain bahwa karakter mempengaruhi pola dalam proses perubahan. Dan yang paling penting ialah karakter mencerminkan sifat dasar dari setiap manusia yaitu ahlak, yang merupakan sifat paling dasar dari manusia dalam menentukan sebuah perubahan dalam mempengaruhi kepribadian dirinya. Dengan konteks ini maka setiap individu akan memberikan reaksi terhadap kondisi yang muncul dari hubungan dengan lingkungan dan psikologinya. Namun dengan kondisi tersebut setiap individu akan menciptakan berbagai formulasi di dalam menentukan sebuah putusan sebagai upaya menyeimbangkan gejolak yang terjadi, bagaimana untuk survive dalam lingkungan yang menuntutnya untuk memainkan corak atau karakternya.

Dengan mengacu pada berbagai penjelasan sebelumnya, maka dapat kita tarik bahwasanya penjelasan dan penjabaran tersebut mengena bahwasanya karakter akan dimulai dalam memaksimalkan sebuah jalan yang bernama pendidikan karakter. Karena pendidikan karakter pada hakekatnya ingin membentuk individu menjadi seorang pribadi bermoral yang dapat menghayati kebebasan dan tanggung jawabnya, dalam relasinya dengan orang lain dan dunianya dalam komunitas pendidikan (Fihris, 2010: 24-28).

Menurut Agus Wibowo bahwa pendidikan karakter adalah pendidikan budi pekerti plus, yaitu pendidikan budi pekerti yang melibatkan aspek pengetahuan (cognitive), perasaan (feeling), dan tindakan (action) (Wibowo, 2013: 38). Menurut Ratna Megawangi yang dikutip oleh Amirulloh Syarbini, bahwa pendidikan karakter adalah sebuah usaha untuk mendidik anak-anak atau individu seseorang agar dapat mengambil keputusan dengan bijak dan mempraktikkannya dalam kehidupan sehari-hari, sehingga mereka dapat 
memberikan kontribusi positif pada lingkungannya (Syarbini, 2014: 12).

Maka dari perkaya penjelasan akan pembahasan karakter serta pendidikan karakter yang secara spesifikasi menjabarkan bahwa tujuan keseluruhanya ialah mengharapkan terciptanya sebuah sikap yang tegak akan nilai-nilai yang mendasar dalam diri setiap manusia. Nilai-nilai dan moral positif yang dibawa hidup bersama dalam konteks bermasyarakat, berbangsa dan bernegara. Karena nilai atau moral inilah yang akan diketahui dan dikenal secara bertahap, karena inipula yang akan menuntun kita setiap yang memiliki corak mendapatkan identitas diri yang sesungguhnya dengan konteks karakteristik yang itu berbeda dengan sifat manusia lainya.

\section{Pandangan Islam akan Pendidikan}

\section{Karakter}

Abdul Majid dan Dian Andayani yang mengutip pembahsan dalam The Journal of Moral Educational yang secara garis besar mengangkat bahwasanya urgensi pendidikan karakter memberikan pesan bahwa nilai-nilai spiritualisasi agama tidak dapat dipisahkan dari pendidikan karakter tersebut. Pendidikan karakter merupakan konsep dan landasan yang strategis dan penting untuk segera dibenahi dari segala lini kehidupan. Karena dalam dunia pendidikan yang tanpa kita sadari haruslah menjalin sebuah jalan penghubung yang sudah nyaris putus antara pegiat pendidikan. Karena pendidikan karakter yang prinsipal akan terbangun karena komunikasi dan keselarasan antara keluarga, masyarakat dan negara. Karena diharapkan education network daat berjalan saling berkesinambungan satu dengan yang lainya dalam membentuk pendidikan karakter yang sesuai dengan nilai-nilai agama, sosial dan kemanusiaan.

Dalam ajaran Islam, tidak ada disiplin ilmu yang terpisah dari etika-etika Islam. Dan pentingnya komparasi antara akal dan wahyu dalam menentukan nilainilai moral yang terbuka bagi kebanyakan muslim. Karena segala yang dianggap halal dan haram dalam Islam, dipahami sebagai keputusan Allah tentang benar dan baik. Dalam Islam terdapat tiga nilai utama, yaitu akhlak, adab, dan keteladanan.

Pembahasan pendidikan karakter dalam Islam membawa kita harus menelaah kajian akan keunggulan ciri khas yang berbeda dengan sebuah nilai pendidikan diluarnya, artinya ajaran islam mengajarkan penempaan nilai-nilai ahlak, adab dan ketauladanan menjadi sebuah lumbung kajian keilmuan yang mendalam. Karena kesemuanya itu merujuk dalam hal-hal yang sangat substansial dalam 
segala sendi kehidupan. Seperti halnya nilai akhlak merujuk kepada tugas dan tanggung jawab selain syari'ah dan ajaran Islam secara umum. Sedangkan adab merujuk kepada suatu sikap yang dihubungkan dengan tingkah laku yang baik. Dan ketauladanan merujuk kepada kualitas karakter terbaik dari seorang Muslim yang mengikuti keteladanan Nabi Muhammad. Ketiga inilai yang menjadi pilar pendidikan karakter dalam Islam.

Maka sangat jelas dalam konteks konsep, pendidikan dalam segala lini akan melahirkan sebuah perbedaan yang dilakukan sebagai bentuk aksiologinya di dalam aplikasi. Ajaran Islam memberikan sebuah identitas yang berbeda dalam menjalankan sebuah titik sebagai upaya penerapan pendidikan karakter dengan dunia Barat. Karena dalam dunia pendidikan Barat proses pendidikannya semata-mata tanggung jawab manusia, tidak dihubungkan dengan tanggung jawab keagamaan, tujuan akhir pendidikannyapun ialah memperoleh kehidupan sejahtera dalam arti materealistik semaksimal mungkin. Ini tentu berbeda dengan konsep pendidikan Islam, yang semua aktivitas pendidikan haruslah dikaitkan dengan perwujudannya sebagai hamba Allah dan sebagai khalifah.

Islam memiliki keunikan dan berbeda dengan konteks penekanan nilainilai prinsip spiritual agama yang abadi.
Karena penekanan aturan dan hukum dalam memperkuat nilai moralitas, perbedaan pemahaman akan kebenaran, penolakan akan pendidikan moral dijadikan sebuah nilai otonom akan tujuan moralitas semata dan penekanan bahwa moral merpakan nilai motivasi keyakinan akan kehidupan setelah mati. Perbedaan inilah yang menjadikan keberadaan wahyu Ilahi sebagai rambu sumber hukum dan pendidikan karakter dalam Islam. Maka akibatnya, pendidikan karakter dalam Islam lebih sering dilakukan secara doktriner dan dogmatis tidak secara demokratis dan logis.

\section{Pendidikan Karakter dalam}

\section{Membentuk Insan Kamil}

Menurut Hamdani Hamid dan Beni Ahmad Saebani bahwa pendidikan karakter bertujuan membentuk insan kamil. Kurikulum yang membangun karakter insan kamil dalam perspektif Islam memiliki ciri-ciri khusus sebagai berikut (Hamid, 2013: 41): (a) Pembinaan anak didik untuk bertauhid. Dalam konteks ini proses menunggalkan sang pencipta di dalam benak dan menjadi nilai sakral yang tidak bisa dipisahkan dalam rutinitas kehidupan manusia. Kurikulum harus disesuaikan dengan fitroh manusia. Sebagai makhluk yang memiliki keyakinan kepada Tuhan manusia haruslah meyakini kesebenaranya 
bahwa yang memiliki kemutlakan dalam menentukan segala putusan ialah Allah. (c) Kurikulum yang disajikan merupakan basil pengujian materi dengan landasan alQuran dan as-Sunnah sebagai sumber segala hukum dalam ajaran Islam. (d) Mengarahkan minat dan bakat serta meningkatkan kemampuan akidah anak didik serta keterampilan yang akan diterapkan dalam kehidupan konkret. Kemampuan dan kapasitas diri dari setiap individu yang diarahkan kedalam kondisi ruhaniah yang bersandar dalam ketentuan syariat agama. (e) Pembinaan akhlak anak didik, sehingga pergaulannya tidak keluar dari tuntunan Islam. Karena dalam tataran pemaknaan ahlak yang sesungguhnya ialah perangai dan segala upaya yang dilakukan akan mencerminkan tindak tanduk diri seorang muslim. (f) Tidak ada kedaluwarsa kurikulum karena ciri khas kurikulum Islam senantiasa relevan dengan perkembangan zaman, bahkan menjadi filter kemajuan ilmu pengetahuan dan teknologi dalam penerapannya dikehidupan masyarakat. (g) Pendidikan karakter mengisyaratkan tiga macam dimensi dalam upaya mengembangkan kehidupan manusia yaitu: dimensi kehidupan duniawi yang mendorong manusia sebagai hamba Allah untuk mengembangkan dirinya dalam ilmu pengetahuan, keterampilan dan nilai-nilai Islam yang mendasari kehidupan. Dimensi kehidupan ukhrawi yang mendorong manusia untuk mengembangkan dirinya dalam pola hubungan yang serasi dan seimbang dengan Tuhan. Dimensi inilah yang melahirkan berbagai usaha agar seluruh aktivitas manusia senantiasa sesuai dengan nilai-nilai Islam dan dimensi hubungan antara kehidupan duniawi dan ukhrawi yang mendorong manusia untuk berusaha menjadikan dirinya sebagai hamba Allah yang utuh dan paripurna dalam bidang ilmu pengetahuan dan keterampilan, serta menjadi pendukung dan pelaksana ajaran Islam. Ketiga dimensi itu kemudian dituangkan dan dijabarkan dalam program operasional pendidikan yang bermuara pada tujuan yang telah ditetapkan.

\section{Burhanuddin Al-Zarrnuji dalam Prinsip Pendidikan Karakter}

Grunebaum dan Abel mengatakan bahwa Burhanuddin az zarnuji adalah toward the end of $12^{\text {th }}$ and beginning of $13^{\text {th }}$ century A.D. demikian pula mengenai daerah tempat kelahirannya yang pasti. Namun jika dilihat dari nisbahnya, yaitu az Zarnuji, maka sebagian peneliti mengatakan bahwa ia berasal dari Zaradj. Dalam hubungan ini Mochtar Affandi mengatakan: it is a city in Persia which was formally a capital and city of Sadjistan to the south of Heart (now 
Afganistan). Pendapat senada juga dikemukakan Abd al Qadir Ahmad yang mengatakan bahwa az Zarnuji berasal dari suatu daerah yang kini dikenal dengan nama Afganistan (Nata, 2003: 103-104).

Konsep pemikiran Zarnuji dalam dunia pendidikan sudah tidaklah diragukan keberadaannya, baik dari kalangan massyarakat muslim maupun oleh para tokoh peneliti orientalis dari dunia Barat. Ada sebuah hasil penelitian yang dilakukan dari dunia barat yang dimana menyoal dan menyinggung keberadaan konsep pendidikan dari kitab karangan Zarnuji Ta'lim al-Muta'allim Thuruq alTa'allum. Keberadaan kitab ini menarik para peneliti Barat untuk menukil berbagai spekulasi dalam membangun konten dalam dunia pendidikan yang bukan hanya urusan keduniawian semata. Jauh dari situ az-Zarnuji memandang kontens pendidikan Islam jauh lebih flaksibel dalam menentukan araf kemana sesungguhnya segala unsur ilmu pengetahuan bermuara. Diantara tulisan yang menyinggung kitab ini dapat dikemukakan antara lain: G.E. Von Grunebaum dan T.M. Abel yang menulis Ta'lim al Muta'allim Thuruq al-Ta'allum; Intruction of the Students: The Method of Learning; Carl Brockelmann dengan bukunya Geshicte der Arabischen Litteratur; Mehdi Nakosten dengan tulisannya History of Islamic Origins of
Western Education A.D. 800-1350, dan lain sebagainya (Nata, 2003: 107).

Di Indonesia sendiri, kitab Ta"lim al-Muta"allim sangat familer dalam dunia pendidikan Islam. Yang itu dapat kita lihat dari corak dan model pendidikan yang ada di pondok-pondok pesantren hampir diseluruh wilayah Indonesia. Mulai dari pondok tradisional hingga pondok pesantren modern banyak mengadopsi pola dan konsep pendidikan yang dikemukakan oleh Zarnuji. Seperti halnya pondok Modern Gontor yang banyak menjadikan konsep tersebut sebagai pola di dalam mendidik dan menanamkan nilainilai moral sebagai bentuk interpretasi Islam yang Rahmatan lil a'lamin. Sedangkan untuk dunia pondok pesantren yang tradisional sudah tidak dielakkan lagi hampir dalam seluruh sendi kehidupan pesantren menggunakan hal yang serupa.

Sesungguhnya secara rinci dari kiteb tersebut kita dapat mengetahui konsep Islam mengajarkan pendidikan karakter yang sangat kompeten sesuai dengan tuntunan ajaran dan syariat. AzZarnuji secara gamblang dan umum menjabarkan terdapat tiga belas pasal yang disingkat-singkat. Adapun isi kitab ini terdiri dari tiga belas bab, yaitu: a). Pasal tentang pengertian ilmu dan fiqh keutamaannya, b). Pasal tentang niat diwaktu belajar, c). Pasal tentang memilih ilmu, guru, teman, dan mengenai 
ketabahan, d). Fasal tentang menghormati ilmu dan ulama, e). Pasal tentang tekun, kontinuitas dan minat, f). Pasal tentang permulaan, ukuran dan tata tertib belajar, g). Pasal tentang tawakkal, h). Pasal tentang pendapatan buah hasil ilmu, i). Pasal tentang kasih sayang dan nasihat, j). Pasal tentang istifadah, k). Pasal tentang wara di kala belajar, 1). Pasal tentang penyebab hafal dan lupa, m). Pasal tentang pendatang dan penghalang rizki, serta pemanjang dan pengurang ilmu (Iqbal, 2015: 378).

Namun dalam konteks ini dapat disajikan kedalam tiga bagian besar yang mencakup; 1). The Division of Knowledge (pembagian ilmu), 2). The Purpose of Learning (tujuan pendidikan) dan 3). Methode of Study (metode pembelajaran (Iqbal, 2015: 109-110), Seperti: (1) Pembagian Ilmu. Dalam konteks ini Zarnuji melakukan sebuah konsep yang dimana dalam melakukan sebuah proses pendidikan dan mendidik dalam menciptakan sebuah nilai yang pondasi perlu melakukan sebuah pembagian ilmu. Konsep tersebut beliyau tuangkan dalam landasan bahwasanya dalam membagi ilmu menjadi dua bagian besar; pertama, ilmu yang bersifat fardu a'in dan fardu kifayah. Konteks fardu $a$ 'in ialah setiap muslim secara individual wajib mempelajarinya ilmu-ilmu agama seperti ilmu fiqh dan ilmu ushul (dasar- dasar agama). Sedangkan dalam konteks fardu kifayah dijelaskan dengan tataran yang bahwasanya setiap individu muslim sebagai suatu komunitas, bukan sebagai individu diharuskan menguasainya, seperti ilmu pengobatan, ilmu astronomi dan lain sebagainya. (2) Tujuan Pendidikan. Terkait dengan hal tersebut, Zarnuji memberikan penjelasan bahwasanya secara hakikat tujuan pendidikan ialah mencari keridhoan Allah semata. Dengan proses berjalannya waktu dengan hendak untuk mendambakan kebahagiaan dunia dan ahirat, memerangi kebodohan bagi diri sendiri dan orang lain, mengembangkan ajaran Islam dan melestarikannya, serta mensyukuri nikmat Allah akan ilmu tersebut. Dalam keterkaitanya hubungan ini Zarnuji memberikan sebuah rambu jangan sampai para penuntut ilmu salah niat dalam belajar. Misalnya belajar untuk mendapatkan sebuah pengakuan dan pengaruh dalam kehidupan, serta menjadikan ilmu pengetahuannya tersebut sebgaia tameng di dalam melakukan pemanipulasian keilmuan dan menjadikan sebuah ketidak harmonisan akibat pengaruh yang ditimbulkannya. Karena efek keinginan dan ketamakan di dalam mencari pengakuan yang bersifat duniawi, seperti riya', harta, jabatan, sombong dan lainya. Namun jika masalah niat ini sudah 
benar, maka ia akan merasakan kelezatan ilmu dan amal, serta akan semakin berkuranglah kecintaannya terhadap harta benda dan dunia. (3) Metode Pembelajaran. Metode atau cara belajar dan mengajarkana sebuah ilmu memiliki pola dan karakter sendiri-sendiri di dalam prosesnya. Namun dalam kali ini Zarnuji membagi pola metode tersebut kedalam dua pembahasan, pertama metode yang bersifat etik dan kedua yang bersifat strategi. Metode yang bersifat etik ialah metode belajar yang didasari dari dalam kesadaran dan tampa paksaan untuk menimba sebeuah ilmu. Artinya niat belajarlah yang menjadi titi awal di dalam menuntut ilmu bagi setiap insan. Sedangkan cara atau strrategi ialah merupakan sebuah metode yang dilakukan dalam menentukan taktik menjalankan sebuah pekerjaan. Dalam hal ini memilih pelajaran, memilih guru dan teman merupakaan jalan dalam belajar. Konteks ini diangap dapat menjadi sebuah jalan yang sesuai dalam melakukan sebuah proses penempaan ilmu pengetahuan yang bertujuan terciptanya karakter.

Dua klasifikasi menurut penelitian Grunebaum dan Abel atas gagasan yang dikemukakan oleh Zarnuji terkait dengan metode belajar dalam membentuk pendidikan karakter, yang diantaranya terkait dengan dua kategori utama. Pertama, yang berhubungan etik religi, dan kedua yang berhubungan dengan aspek teknik pembelajaran. Adapun yang termasuk kedalam katagori pertama ialah mengharuskan para pelajar untuk mempraktikan mengamalkan beberapa amalan-amalan agama tertentu. Prosesi tersebut menurutnya merupakan suatu perkara yang allogical, atau tidak dapat didiskusikan secara nalar akan atau logical stetment. Sebagai contoh alZarnuji mengatakan bahwa untuk dapat diberikan rizki, hendaknya setiap pelajar dianjurkan untuk membaca Subhanallah al'azim, subhanallah wa bihamdih sebanyak seratus kali.

Mengenai kategori kedua, yakni aspek teknik pembelajaran, menurut Grunebaum dan Abel terhadap enam hal yang menjadi sorotan Zarnuji, yaitu: 1). The curriculum and the subject matter (kurikulum dan materi pelajaran), 2). The choise of setting and teacher (pilihan pengaturan dan guru), 3). The time for study (waktu pembelajaran), 4). Techniques for learning and manner for study (teknik untuk belajar dan cara untuk belajar), 5). Dynamics of learning (dinamika belajar), dan 6). The students relationship to others (hubungan siswa dengan orang lain). 


\section{KESIMPULAN}

Berdasarkan hasil dan pembahasan di atas dapat disimpulkan bahwa kitab Ta'lim al-Muta'allim semakin memberikan angin segar dalam penerapan metode keilmuan pendidikan karakter sesuai dengan syariat Islam. Pemikiran Burhanuddin al-Zarnuji dalam kitab Ta'lim al- Muta'allim melahirkan konsep karakter unggul dan Islami. Karangannya fenomenal dan menjadi sebuah rujukan kontemporer bersamaan dengan kajian keilmuan dalam dunia pendidikan miliknnya Imam al-Ghazali dalam kitabnya Ayyuha al- Walad yang menerangkan tentang pendidikan karakter akan bermuara pada sebuah pemahaman keilmuan yang semata hanyalah mililk Allah. Dan konsep tersebut bukanlah semata dalam kajian keilmuan Islam, namun jauh disitu terdapat konsep yang dilakukan oleh dunia pendidikan Barat.

\section{DAFTAR PUSTAKA}

Departemen Agama RI. (2000). AlQur'an dan Terjemahnya. Jakarta: PT. Intermasa.

Iqbal, A. M. (2015). Pemikiran Pendidikan Islam cet. Ke-l. Yogyakarta: Pustaka Pelajar.

Nata, A. (2003). Pemikiran Para Tokoh Pendidikan Islam; Seri Kajian Filsafat Pendidikan Islam. Jakarta: Raja Grafindo Persada.

Amin, A. (2012). Kitab Akhlak Wasiat Terakhir Gus Dur. Surabaya: Quntum Media.
Wibowo, A. (2013). Pendidikan Karakter di Perguruan Tingg. Yogyakarta: Pustaka Pelajar.

Syarbini, A. (2014). Model Pendidikan Karakter dalam Keluarga. Jakarta: Gramedia.

Salahudin, A., \& Alkrienciehie, I. (2013). Pendidikan Karakter Pendidikan Berbasis Agama dan Budaya Bangsa. Bandung: Pustaka Setia.

Daryanto, \& Darmiatun, S. (2013). Implementasi Karakter di Sekolah, Yogyakarta: Gava Media.

Fihris. (2010). Pendidikan Karakter di Madrasah Salafiyah. Semarang: Puslit IAIN Walisongo.

Nashir, H. (2013). Pendidikan Karakter Berbasis Agama dan Budaya. Yogyakarta: Multi Presindo.

Hamid, H., \& Saebani, B. A. (2013). Pendidikan Karakter Perspektif Islam. Bandung: Pustaka Setia.

Asmani, J. M. (2012). Buku Panduan Internalisasi Pendidikan Karakter di Sekolah. Yogjakarta: Diva Press.

Zainuddin, M., dkk. (2009). Pendidikan Islam dari Paradigma Klasik Hingga Kontemporer. Malang: UIN Malang Press.

Samani, M., \& Hariyanto. (2011). Konsep dan Model Pendidikan Karakter. Bandung: Remaja Rosdakarya. 